\title{
Studies on pigs reared on diets low in tocopherol and essential fatty acids
}

\author{
By W. M. F. LEAT \\ School of Agriculture, Cambridge \\ (Received 21 September 1960-Revised 19 December 1960)
}

Although the role of tocopherol in the nutrition of small laboratory animals has been extensively investigated, relatively little attention has been given to the requirement of larger domestic animals. Evidence is conflicting about any function or effect tocopherol may have on pig nutrition. Bratzler, Loosli, Krukovsky \& Maynard (1950) found that tocopherol supplementation of a diet low in tocopherol and fat markedly affected the composition of body fats by increasing the content of oleic acid. Hove \& Seibold (r955) showed that tocopherol supplementation of diets containing $6 \%$ lard and $2 \%$ cod-liver oil increased the content of polyunsaturated fatty acids in muscle and liver. Garton, Duncan, Madsen, Shanks \& Beattie (1958) and Duncan, Garton, McDonald \& Smith (I960) failed to confirm these findings. That tocopherol exerts a protective effect on the oxidation of body lipids of rats has been shown by Barnes, Lundberg, Hanson \& Burr (1943). For the pig, however, evidence is conflicting. Watts, Cunha \& Major (1946) found that supplementing purified rations with tocopherol increased only slightly the stability of pig fat and had no effect when natural diets were supplemented. Carpenter \& Lundberg (1949), however, reported that the induction period, as measured by an oxygen-absorption method, of body fat from pigs fed on a partly purified diet supplemented with tocopherol was longer than that found in the fats from unsupplemented controls.

The experiments reported below were designed to investigate the role of tocopherol in the nutrition of the pig up to $200 \mathrm{lb}$ live weight, special attention being paid to any effect tocopherol might have on the composition and stability of the body lipids. In nearly all the previous experiments reported in the literature, the piglets used were of normal weaning weight $\left(35^{-45} \mathrm{lb}\right)$ in which considerable storage of tocopherol could have already occurred. To prevent the accumulation of too large a reserve of tocopherol, the piglets were weaned within 3 weeks of birth, when they weighed about ro lb. The basal diet used, besides being low in tocopherol, was also low in fat to prevent undue alteration in the composition of the body fat and to prevent the complicating effect that fat has on the requirement for tocopherol.

EXPERIMENTAL

Diet

The composition of the basal diet used in both experiments is shown in Table I together with the analysis of the individual components. 
The diet contained $\mathrm{I} \cdot 0 \%$ steamed bone flour, $\mathrm{I} \cdot 0 \%$ limestone, $0 \cdot 5 \%$ sodium chloride, and $0.25 \%$ trace metals (Adamstone, Krider \& James, 1949). Vitamins A and D were added three times a week at the rate of 2000 i.u. and 500 i.u./lb diet, respectively, as a concentrate in olive oil. Up to 8 weeks of age only, the diet was supplemented with $0.5 \%$ Aurofac-2 A (Lederle Laboratories Inc., containing $3.6 \mathrm{~g}$ chlortetracycline/lb). This diet contained at most $0.13 \mathrm{mg}$ total tocopherols/100 $\mathrm{g}$ diet and $\mathrm{I} \cdot \mathbf{2 2} \%$ ether extract.

\section{Table I. Composition of basal diet and analysis of individual components}

\begin{tabular}{|c|c|c|c|c|c|c|c|}
\hline \multirow[b]{3}{*}{ Ingredient } & & & & \multicolumn{4}{|c|}{ Analysis of dietary components } \\
\hline & \multicolumn{3}{|c|}{ Percentage composition of diet } & \multirow{2}{*}{$\begin{array}{l}\text { Ether } \\
\text { extract } \\
(\%)\end{array}$} & \multirow{2}{*}{$\begin{array}{c}\text { Total } \\
\text { tocopherols* } \\
\text { (mg/roog } \\
\text { meal) }\end{array}$} & \multirow{2}{*}{$\begin{array}{l}\text { Iodine } \\
\text { value } \\
\text { of ether } \\
\text { extract }\end{array}$} & \multirow{2}{*}{$\begin{array}{c}\text { Crude } \\
\text { protein } \\
(\%)\end{array}$} \\
\hline & Up to $40 \mathrm{lb}$ & $40-120 \mathrm{lb}$ & $120-200 \mathrm{lb}$ & & & & \\
\hline Cassava & $27 \cdot 25$ & $47 \cdot 25$ & $57 \cdot 25$ & 0.39 & $O \cdot I I$ & $72 \%$ & $1 \cdot 7$ \\
\hline $\begin{array}{l}\text { Extracted palm-kernel } \\
\text { cake }\end{array}$ & 10.0 & $20 \cdot 0$ & $20 \cdot 0$ & $1 \cdot 40$ & 0.05 & $16 \cdot 5$ & $18 \cdot 2$ \\
\hline Dried brewer's yeast & $5 \cdot 0$ & $5 \cdot 0$ & $5 \cdot 0$ & $0.5 \mathrm{I}$ & 0.08 & $64 \cdot 2$ & $47 \cdot 2$ \\
\hline Dried skim milk & 50.0 & $25^{\circ} 0$ & $15{ }^{\circ}$ & $1 \cdot 52 \dagger$ & 0.18 & $23 \cdot 2$ & 34.7 \\
\hline White-fish meal & $5 \cdot 0$ & - & - & 3.74 & 0.42 & $13 I^{\circ} 0$ & $65 \cdot 6$ \\
\hline Minerals & $2 \cdot 75$ & $2 \cdot 75$ & $2 \cdot 75$ & - & - & - & - \\
\hline
\end{tabular}

\section{Animals}

Expt $\mathrm{x}$. Eight Large White $\times$ Essex piglets were weaned at 17 days and numbered I-8. All were from the same litter except no. 8 which was taken from a litter born at the same place on the same day. The layout of the experiment is shown in Table 2. Pigs nos. I-4 were penned and fed individually, but because of the lack of accommodation, the remainder were penned and fed in pairs, nos. 5 and 6 being one pair and nos. 7 and 8 the other. Sawdust was provided at one end of each pen for bedding and was replaced when soiled. Supplements of olive oil at the expense of an isocaloric weight of cassava were given daily, and $\alpha$-tocopherol succinate (Vitamins Ltd) three times weekly, to the animals shown. The olive oil was incorporated into the diet as a mild antagonist against the small amount of tocopherol contained in the basal diet. Up to $40 \mathrm{lb}$ live weight the animals were fed four times a day and from then on twice daily, the ration size being on a live-weight basis (Woodman \& Evans, 195I). The animals were weighed weekly up to the slaughter weight of $200 \mathrm{lb}$ live weight.

Expt 2. Ten Large White $\times$ Essex piglets from one litter were weaned at 19 days and numbered $\mathrm{r}-\mathrm{IO}$. The basal diet used was modified slightly from that in Expt I, $0.5 \%$ olive oil replacing an isocaloric weight of cassava.

This modification was necessary because the amount of fat in the diet was insufficient to satisfy the requirements of the pig for essential fatty acids (Leat, I959). The layout of the experiment is shown in Table 2. The piglets were randomized according to weight. Pigs nos. $\mathrm{I}$ and 6 were penned and fed individually and the remainder in pairs, i.e. pigs nos. 2 and 3, 4 and 5, 7 and 8, 9 and Io. The amount of food given 
daily to the group given a supplement of tocopherol was the same as to the controls; thus pig no. 6 received the same weight of food as pig no. I, pigs nos. 7 and 8 the same as pigs nos. 2 and 3 , and pigs nos. 9 and to the same as pigs nos. 4 and 5. Other experimental procedure was the same as described for Expt I. Pigs nos. 4, 5, 9 and 10 were slaughtered at about $\mathrm{I}_{5} \mathrm{O} \mathrm{lb}$ live weight and the remaining animals were then penned and fed individually up to $200 \mathrm{lb}$ live weight, when they were slaughtered.

Table 2. Plan of Expts I and 2 showing weight and sex of pigs, food consumption and supplements of $\alpha$-tocopheryl succinate

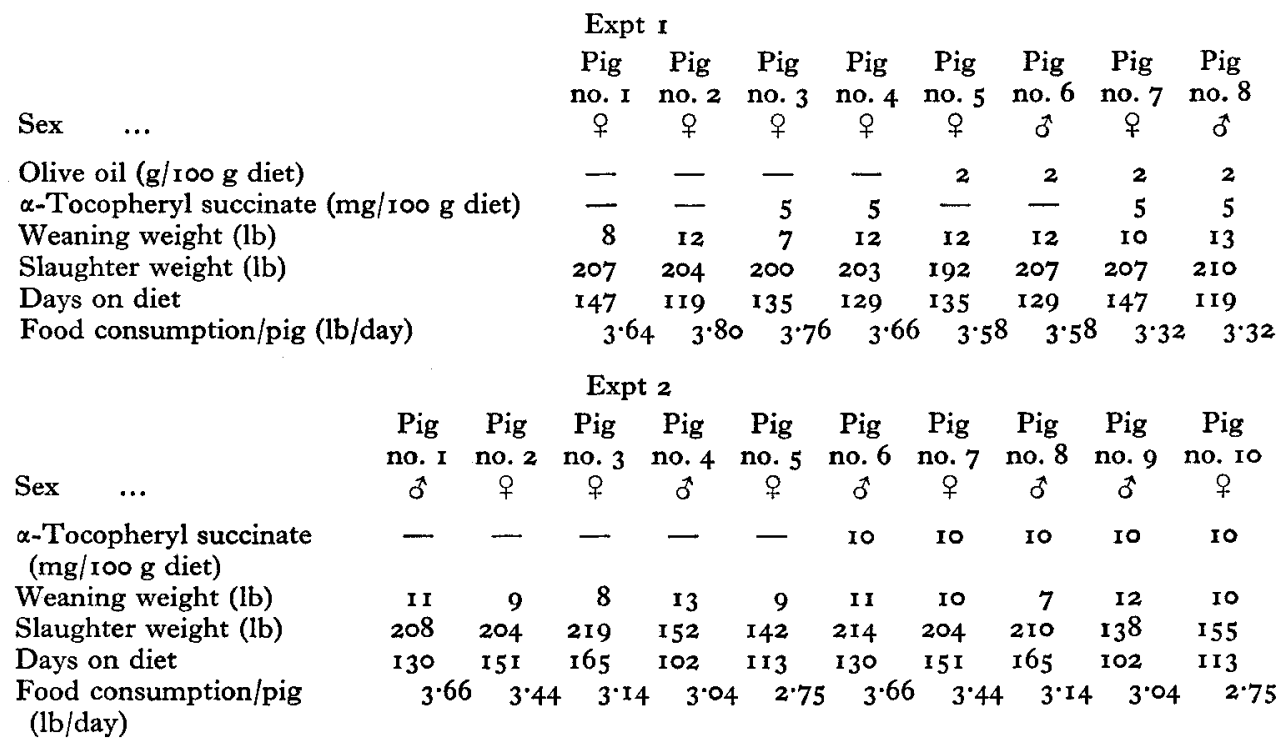

\section{Collection of blood and sampling of tissues}

Collection of blood. Samples were obtained from the tail vein.

Slaughter. The pigs were killed by exsanguination and the blood was collected, defibrinated and centrifuged to obtain the serum. The tissues were examined for abnormalities, and representative samples of liver, heart and back fat were taken. A complete depth of back fat measuring 4 in. $\times 3$ in. was taken from between the shoulder blades and dissected into the inner and outer layers. All tissue samples and serum were stored at $-20^{\circ}$ until required for analysis.

Back-fat samples. Samples of $r o g$ were chopped up and extracted three times with boiling ethanol-diethyl ether $(3: I)$ to remove the crude lipid. The solvent was removed under a stream of nitrogen on a water-bath and the resulting extract rectified with light petroleum (b.p. $40-60^{\circ}$ ) as described by Garton et al. (1958). The last traces of solvent were removed under reduced pressure.

Liver and heart samples. The wet tissues were ground up with a small amount of acid-washed sand in a pestle and mortar to break down the cells, and the lipid was extracted and the extract rectified as described for back fat.

All tissue extracts were stored at $0^{\circ}$ until required for assay. 


\section{Analytical methods}

Solvents. All solvents were purified before use. Light petroleum (b.p. 40-60 $)$ was redistilled. Diethyl ether was distilled over reduced iron just before use. Ethanol was refluxed for $\mathrm{I} h$ with potassium permanganate ( $\mathrm{g} / \mathrm{l}$.) and potassium hydroxide $(2 \mathrm{~g} / \mathrm{l}$.) and then distilled, the first $30 \mathrm{ml}$ of the distillate being rejected.

Chemical methods. The method of Mervyn \& Morton (1959) was used to obtain the non-saponifiable fraction of liver and heart and to estimate the ubiquinone content by subsequent chromatography.

Polyethenoid fatty acids were estimated by the method of Herb \& Riemenschneider (1953) and iodine values by the method of Wijs as described by Hilditch (1949). Total tocopherols (total reducing substances) were determined by the method of Eggitt \& Ward (I953) and peroxide values by the method of Lea (1946).

Plasma unsaturated fatty acids were estimated by the method of Pikaar \& Nijhof (1958) and total tocopherols by the following modification of the method of Kimble (1938-9). Two volumes of plasma were mixed well with an equal volume of ethanol in a glass-stoppered vessel. Five volumes of light petroleum were added and the mixture was well shaken for $10 \mathrm{~min}$. The mixture was allowed to stand until the two layers had separated. Duplicate two-volume portions of the light-petroleum layer were pipetted into separate glass vessels and evaporated to dryness on a water-bath under a stream of nitrogen. The residue was dissolved in $3 \mathrm{ml}$ ethanol and the total tocopherols were measured directly by the method of Eggitt \& Ward (1953) without further purification.

The erythrocyte-haemolysis test with dialuric acid was carried out by the method of Rose \& György (I952). Spontaneous haemolysis of red blood cells in $0.9 \%$ saline was investigated as follows. A $5 \%$ suspension of red blood cells in $0.9 \%$ saline from each animal was prepared as described by Rose \& György (1952). Portions of Io $\mathrm{ml}$ were transferred to test tubes and allowed to stand at room temperature. The tubes were inverted twice or three times when the cells began to settle out, each tube receiving the same amount of agitation. When one or more tubes showed appreciable haemolysis $(48-96 \mathrm{~h})$, the degree of haemolysis in each tube was measured as described by Rose \& György (I952).

The Hilger Uvispek instrument was used for all spectrophotometric readings. Oxygen-free nitrogen (containing less than ro volumes oxygen per million volumes of nitrogen) was used throughout.

\section{RESULTS \\ Expt I}

After I 3 weeks on the diet, pigs nos. I-4 began to show signs of what was presumed to be a deficiency of essential fatty acids, characterized by a dry flaking skin on the back which was very pronounced around the shoulders. Witz \& Beeson (I95I) reported similar signs in pigs raised on diets low in fat. A preliminary report of the condition has been published (Leat, r959) and a more detailed account will be published later.

There was no difference in growth rate or efficiency of food conversion between the animals given a supplement of tocopherol and their controls. At slaughter all the 
organs appeared normal with no discoloration of the back fat, but the skins of pigs nos. I-4 had a pin-point red rash along the back and shoulders. All carcasses and organs were accepted for human consumption.

Table 3 shows the susceptibility of the erythrocytes to spontaneous haemolysis in $0.9 \%$ saline. It will be seen that when haemolysis had become quite extensive in pigs nos. 5, 6, 7 and 8 , relatively little had occurred in pigs nos. $1,2,3$ and 4 . It was a consistent finding that haemolysis always occurred earlier in the red blood cells from animals given $2 \%$ olive oil than in those on a low-fat diet. On only one occasion did tocopherol have any effect on the degree of haemolysis noted. The results of the haemolysis test with dialuric acid were always negative and it would appear that the red blood cells of the pig are not susceptible to this reagent.

Table 3. Expt I. Tocopherol levels in tissues of pigs and susceptibility of erythrocytes to haemolysis (for treatment see Table 2)

Total tocopherols in:

Plasma $(\mu \mathrm{g} / 100 \mathrm{ml})$

Liver (mg/roo g)

Back fat (mg/roo g)

Back fat: iodine value linoleic-acid content $(\%)$

Haemolysis of erythrocytes (\%) at: 14 weeks

$\begin{array}{cccccccc}\begin{array}{c}\text { Pig } \\ \text { no. I }\end{array} & \text { Pig } & \text { Pig } & \text { Pig } & \text { Pig } & \text { Pig } & \text { Pig } & \text { Pig } \\ \text { no.3 } & \text { no. } 4 & \text { no. } 5 & \text { no.6 } & \text { no. } 7 & \text { no. } 8 \\ 54 & 106 & 360 & 237 & 60 & 41 & 143 & 304 \\ 0.58 & 0.60 & 1.05 & 1.44 & 0.69 & 0.76 & 1.21 & 0.76 \\ 1.0 & - & - & 0.88 & 0.25 & - & 1.12 & - \\ - & - & - & 50.0 & - & 52.5 & - & 54.1 \\ - & - & - & 0.27 & - & 1.07 & - & 1.90 \\ - & 5 & 0 & - & 60 & - & 50 & - \\ -0 & - & - & 5 & - & 20 & \frac{1}{8} & 50 \\ - & 15 & 0 & - & 70 & - & - & 75\end{array}$

Expt 2

All animals grew well throughout the experiment and there was no difference in growth rate or efficiency of food conversion between the animals given tocopherol and their controls. The skin and hair of all the pigs had a dry appearance with some scaliness along the back, but to a much lesser degree than found in Expt 1 . It was thought that, although the content of fat in the diet had been raised by the addition of $0.5 \%$ olive oil, the pigs could still suffer from a deficiency of essential fatty acids. This conclusion was borne out by the plasma levels of unsaturated fatty acids. Plasma samples had been taken half-way through the experiment and again at slaughter and analysed for unsaturated fatty acids. The results at slaughter are recorded in Table 4.

On comparing the respective levels of unsaturated fatty acids at the end of the experiment with those at the half-way stage no difference was found in the levels of the diethenoid fatty acid (linoleic) but a $70 \%$ rise in the level of the trienoic acid. A rise in the content of this trienoic acid indicates an insufficiency of essential fatty acids, as noted with the rat (Rieckehoff, Holman \& Burr, 1949), the dog (Wiese, Hansen \& Baugham, 1957), the chick (Reiser, I95 I) and also the pig (Leat, unpublished results). More information and a more detailed discussion will be published later.

At slaughter, no abnormalities were noticed in any organs and neither the back fat nor the uteri were discoloured. In Table 5 are recorded the iodine values and un- 
Table 4. Expt 2. Plasma content of unsaturated fatty acids of pigs at slaughter (for treatment see Table 2)

\begin{tabular}{|c|c|c|c|c|c|c|}
\hline \multirow[b]{2}{*}{ Pig no. } & \multicolumn{4}{|c|}{ Polyethenoid fatty acids ( $\mathrm{mg} /$ roo $\mathrm{ml}$ plasma) } & \multirow{2}{*}{$\begin{array}{l}\text { Total plasma } \\
\text { fatty acids } \\
(\mathrm{mg} / \mathrm{ro0} \mathrm{ml})\end{array}$} & \multirow{2}{*}{$\begin{array}{l}\text { Iodine valt } \\
\text { of total fat } \\
\text { acids }\end{array}$} \\
\hline & Diethenoid & Triethenoid & Tetraethenoid & Pentaethenoid & & \\
\hline $\mathbf{x}$ & $9 \cdot 0$ & 10.6 & $4 \cdot 8$ & $2 \cdot 0$ & 174 & 100 \\
\hline 2 & $7 \cdot 5$ & $12 \cdot 8$ & $4 \cdot 9$ & $1 \cdot 5$ & I53 & 116 \\
\hline 3 & $8 \cdot 2$ & 13.4 & $6 \cdot 3$ & $2 \cdot 5$ & 156 & 107 \\
\hline 4 & $8 \cdot 2$ & $9 \cdot 4$ & $3 \cdot \overline{8}$ & 0.9 & 177 & 107 \\
\hline 5 & $9 \cdot 0$ & II $\cdot 9$ & 3.7 & $I \cdot 3$ & 226 & 105 \\
\hline Mean & $8 \cdot 4$ & $11 \times 6$ & $4 \cdot 7$ & $1 \cdot 6$ & I77 & 107 \\
\hline 6 & $9 \cdot 6$ & $11 \cdot 9$ & $5 \cdot 4$ & $I \cdot 9$ & 200 & 92 \\
\hline 7 & $7 \cdot 7$ & $1 x \cdot 6$ & $5 \cdot 8$ & $2 \cdot 2$ & 164 & rog \\
\hline 8 & $8 \cdot \pi$ & $9 \cdot 6$ & $4 \cdot 2$ & $\mathbf{I} \cdot \mathbf{I}$ & 160 & 112 \\
\hline 9 & $10 \cdot 3$ & $11 \cdot 3$ & $4 \cdot 0$ & 0.1 & 164 & II2 \\
\hline Io & $9 \cdot 2$ & II.9 & $4 \cdot 6$ & $1 \cdot 2$ & 160 & 106 \\
\hline Mean & $9 \cdot 0$ & II $\cdot 3$ & $4 \cdot 8$ & $1 \cdot 3$ & I70 & 106 \\
\hline
\end{tabular}

Table 5. Expt 2. Unsaturation of back fats of pigs (for treatment see Table 2)

\begin{tabular}{|c|c|c|c|c|c|}
\hline Pig no. & $\begin{array}{l}\text { Iodine } \\
\text { value }\end{array}$ & Diethenoid & Triethenoid & Tetraethenoid & $\begin{array}{l}\text { Monoethenoid } \\
\text { (by difference) }\end{array}$ \\
\hline I & $5 \times \cdot 5$ & 0.86 & 0.32 & 0.15 & $54^{\circ} \circ$ \\
\hline 2 & 520 & 0.86 & 0.36 & 0.14 & 54.4 \\
\hline 3 & $55^{\circ} \cdot$ & 0.75 & 0.29 & 0.11 & $58 \cdot 3$ \\
\hline 4 & $53 \cdot 6$ & $x \cdot 02$ & 0.39 & 0.19 & 55.7 \\
\hline 5 & $54 \cdot 8$ & $1 \cdot 00$ & 0.42 & 0.13 & $57 \cdot 1$ \\
\hline Mean & 53.4 & 0.9 & 0.36 & 0.14 & 55.9 \\
\hline 6 & $5 \mathrm{I} \cdot 8$ & 0.91 & 0.33 & 0.15 & $54 \cdot 1$ \\
\hline 7 & $52 \cdot 7$ & 0.93 & 0.34 & 0.10 & 55.2 \\
\hline 8 & 53.8 & 0.76 & 0.30 & $0 \cdot 11$ & $57 \cdot 0$ \\
\hline 9 & $51 \cdot 6$ & $I \cdot 15$ & $0.4 \mathrm{I}$ & 0.20 & $53^{\circ} \circ$ \\
\hline 10 & $54 \cdot \mathrm{I}$ & 0.75 & 0.32 & 0.10 & $57 \cdot 2$ \\
\hline Mean & $52 \cdot 8$ & 0.9 & 0.34 & 0.13 & $55 \cdot 3$ \\
\hline
\end{tabular}

Table 6. Expt 2. Polyethenoid fatty acids from liver and heart of four pigs (for treatment see Table 2)

\begin{tabular}{|c|c|c|c|c|c|c|}
\hline \multirow{2}{*}{$\begin{array}{l}\text { Pig } \\
\text { no.* }\end{array}$} & \multirow{2}{*}{$\begin{array}{l}\text { Iodine } \\
\text { value }\end{array}$} & \multicolumn{5}{|c|}{ Polyethenoid fatty acids (as percentage of total fatty acids) } \\
\hline & & Diethenoid & Triethenoid & Tetraethenoid & Pentaethenoid & Hexaethe \\
\hline & \multicolumn{6}{|c|}{ Liver } \\
\hline $\mathbf{I}$ & I 18 & $3 \cdot 4$ & $8 \cdot 1$ & $9 \cdot \mathbf{I}$ & $2 \cdot 8$ & $\mathbf{2} \cdot \mathbf{I}$ \\
\hline 4 & 109 & $4 \cdot 3$ & $7 \cdot 3$ & $7 \cdot 4$ & $2 \cdot 6$ & $3 \cdot 6$ \\
\hline 6 & II 9 & $3 \cdot 4$ & $8 \cdot 3$ & $9 \cdot 2$ & $3 \cdot 1$ & $1 \cdot 5$ \\
\hline 9 & II3 & $3 \cdot 6$ & $8 \cdot 2$ & $6 \cdot 9$ & $2 \cdot 7$ & $2 \cdot 5$ \\
\hline \multicolumn{7}{|c|}{ Heart } \\
\hline I & I 6 & 16.7 & $7 \cdot 8$ & $5 \cdot 3$ & $\mathbf{1} \cdot 7$ & 0.3 \\
\hline 4 & 114 & 20.0 & $7 \cdot 2$ & $5 \cdot 0$ & $1 . \dot{8}$ & 0.6 \\
\hline 6 & 105 & 14.9 & $6 \cdot 4$ & 3.9 & $I \cdot 2$ & 0.3 \\
\hline 9 & II 3 & 19.3 & $7 \cdot 4$ & $4 \cdot 2$ & $1 \cdot 6$ & 0.5 \\
\hline
\end{tabular}

- Pigs nos. 1 and 4 without, and pigs nos. 6 and 9 given, tocopherol supplement. 
saturated fatty-acid contents of the back fats. Table 6 gives the iodine value and content of polyethenoid fatty acids in the fatty acids of the liver and heart of two pigs given tocopherol and of their corresponding controls.

The total tocopherol levels of plasma, liver, heart and back fat, the ubiquinone level of liver and the peroxide numbers of fatty acids from liver and back fat are recorded in Table 7. The samples of back fat and liver fatty acids had been stored for 9 months at $0^{\circ}$ before assay for peroxides.

All carcasses and organs were accepted for human consumption.

Table 7. Expt 2. Tocopherol content of various tissues of pigs, peroxide number of fatty acids from liver and back fat, and ubiquinone in liver (for treatment see Table 2)

\begin{tabular}{|c|c|c|c|c|c|c|c|}
\hline \multirow[b]{2}{*}{$\begin{array}{l}\text { Pig } \\
\text { no. }\end{array}$} & \multicolumn{4}{|c|}{ Total tocopherols } & \multicolumn{2}{|c|}{$\begin{array}{c}\text { Peroxide number } \\
\text { of fatty acids } \\
(\mu \text { moles } / \mathrm{g})\end{array}$} & \multirow{2}{*}{$\begin{array}{c}\text { Liver } \\
\text { ubiquinone } \\
(\mathrm{mg} / 100 \mathrm{~g})\end{array}$} \\
\hline & $\begin{array}{c}\text { Plasma } \\
(\mu \mathrm{g} / 100 \mathrm{ml})\end{array}$ & $\begin{array}{c}\text { Liver } \\
(\mathrm{mg} / 100 \mathrm{~g})\end{array}$ & $\begin{array}{c}\text { Heart } \\
(\mathrm{mg} / \mathrm{l} 00 \mathrm{~g})\end{array}$ & $\begin{array}{c}\text { Back fat } \\
(\mathrm{mg} / \mathrm{I} 00 \mathrm{~g})\end{array}$ & Liver & Back fat & \\
\hline I & 39 & 0.54 & $2 \cdot 00$ & 0.45 & - & 65 & 470 \\
\hline 2 & 53 & 0.45 & $\mathbf{I} \cdot 68$ & $0.3^{8}$ & 84 & 23 & 435 \\
\hline 3 & $4^{8}$ & 0.55 & $2 \cdot 63$ & $0 \cdot 16$ & 136 & 37 & 4.25 \\
\hline 4 & 26 & 0.72 & $x \cdot 70$ & 0.33 & - & 54 & $5 \cdot 17$ \\
\hline 5 & 30 & 0.78 & $1 \cdot 70$ & 0.71 & 116 & 49 & $4 \cdot 55$ \\
\hline 6 & 457 & 0.67 & $2 \cdot 10$ & 0.59 & 一 & 2 & $3 \cdot 42$ \\
\hline 7 & 439 & 0.82 & $\mathbf{I} \cdot 66$ & 0.34 & 24 & I & 4.40 \\
\hline 8 & 348 & 0.92 & $2 \cdot 07$ & 0.28 & 7 & 2 & $4 \cdot 85$ \\
\hline 9 & 354 & $I \cdot 44$ & $3 \cdot 00$ & 0.97 & 一 & I & $4 \cdot 80$ \\
\hline IO & 407 & $\mathbf{I} \cdot \mathbf{2 8}$ & $2 \cdot 43$ & $1 \cdot 10$ & II & $\mathbf{I}$ & 3.70 \\
\hline
\end{tabular}

\section{DISCUSSION}

\section{Plasma-tocopherol levels}

There is some disagreement in the literature on whether dietary tocopherol raises the plasma-tocopherol values in the pig. Hove \& Seibold (1955) found that $150 \mathrm{mg}$ DL- $\alpha$-tocopheryl acetate/animal daily for up to 187 days did not raise the level of tocopherol in the plasma. Garton $e t$ al. (1958) gave 1o $\mathrm{mg}$ DL- $\alpha$-tocopheryl acetate/ $\mathrm{kg}$ body-weight daily for $\mathrm{I2}-\mathrm{I} 3$ weeks and found no elevation in plasma values. On the other hand, Bratzler et al. (1950) found that supplementing a tocopherol-deficient diet with 3,55 or $\mathrm{r}$ 10 $\mathrm{mg}$ mixed tocopherols/kg body-weight daily for 75 days raised the plasma-tocopherol values to 248,668 or $594 \mu \mathrm{g} / \mathrm{roo} \mathrm{ml}$, respectively. Duncan et al. (1960) gave $20 \mathrm{mg}$ DL- $\alpha$-tocopheryl acetate/kg body-weight daily for 8-ro weeks and found the plasma-tocopherol level to range from $287-663 \mu \mathrm{g} / \mathrm{roo} \mathrm{ml}$. In the experiments reported now, the plasma from animals fed on a diet low in tocopherol had very low levels of tocopherol $(26-53 \mu \mathrm{g} / \mathrm{roo} \mathrm{ml})$, similar to the values obtained by Garton et al. (1958) and Hove \& Seibold (1955). However, the plasma-tocopherol levels of animals given DL- $\alpha$-tocopheryl succinate $(348-457 \mu \mathrm{g} / \mathrm{IoO} \mathrm{ml})$ were elevated to the range found by Bratzler et al. (1950) and Duncan et al. (1960). It is difficult to reconcile these differing sets of results. It is evident that variations in the fat content of the diet will not explain the difference. It would be expected that a low-fat diet would 
adversely affect the absorption of $\alpha$-tocopherol and that increasing the fat content would improve absorption. However, the diets used when the highest levels of plasma tocopherol were noted contained very little fat, and one of the lowest levels of plasma tocopherol recorded was by Hove \& Seibold (I955) with a diet containing $8 \%$ fat. This finding is borne out by the observations of Duncan et al. (1960) who noted that tocopherol was absorbed as effectively from an almost fat-free diet as from one containing $5 \%$ of lard.

\section{Tocopherol levels in liver and heart}

The very large difference in the plasma levels of tocopherol between the animals given tocopherol and the controls was not paralleled in liver and heart. The levels of tocopherol in the livers of the former were about $40 \%$ higher than in those of the controls, but there was no obvious difference in the tocopherol levels of heart which, however, were two to seven times higher than the corresponding liver levels. The chemical method used by me for estimating total tocopherols is open to criticism because the Emmerie-Engel reagent is not specific for tocopherols and will react with other reducing materials that may be present in the extract. The values recorded here are therefore a measure of total reducing substances and will tend to err on the high side. Although not a true record of the absolute level of tocopherol, these values are useful for comparison of animals given tocopherol with their controls. Edwin, Diplock, Bunyan \& Green (1960) point out the necessity of further resolution by means of paper chromatography before an accurate estimate of the tocopherol content of tissues can be made.

Although the increase in tocopherol content of the liver of the animals given tocopherol over that in the controls was small, there was a marked effect on the susceptibility of the lipids to peroxidation. The mean peroxide value for the liver lipids of the controls was I I $2 \mu$ moles/g compared with I $4 \mu$ moles/g for the animals given tocopherol.

It was noted during the extraction procedure that the non-saponifiable fractions from the livers of the group given tocopherol were noticeably yellower in colour than those from the controls. This difference might reflect different levels in carotenoids or ubiquinone, which are known to occur in liver. In view of the possibility at that time that tocopherol and ubiquinone might be related (Slater, 1958), ubiquinone was separated and estimated by chromatography. The results (Table 7 ) show no difference between the two groups, in agreement with other work (Gloor \& Wiss, I 959; Morton \& Phillips, 1959). The differences in yellow colour were most marked in those fractions known to carry carotenoids and xanthophylls, but the characteristic spectrum of these compounds could not be detected, possibly because of the small amounts present and masking by impurities. In the chromatographic fractions of the livers of the pigs given tocopherol, but not in the controls, tocopherol quinone was detected, which would also tend to colour the non-saponifiable fraction yellow and might partly account for the colour difference. The differences in colour can therefore probably be attributed to different levels of carotenoids and tocopheryl quinone. The presence of tocopheryl quinone in the livers of the group given tocopherol confirmed that the dietary tocopherol had been absorbed and had reached the liver. 


\section{Tocopherol and peroxide content of back fat}

Although the level of total tocopherols in the back fat of the pigs given tocopherol was only slightly higher than in that of the controls, there was a very pronounced difference in the respective peroxide content. The fat of the control animals had a peroxide level thirty times higher than that found in the group given tocopherol. The measurements were done on samples that had been stored for 9 months at $0^{\circ}$ and thus it was not possible to say whether these levels of peroxide occurred in vivo or were formed in storage. The finding that tocopherol exerts a powerful depressant effect on the formation of peroxides in pig fat agrees with that of Carpenter \& Lundberg (I949), but not with that of Watts et al. (1946). A possible explanation of these conflicting findings is that in the experiments of Watts et al. (1946) the period of tocopherol supplementation was short and the total amount of tocopherol ingested was correspondingly small.

Chipault, Lundberg \& Burr (1945) found that the stability of pig fat was dependent on both the tocopherol and the linoleic-acid content. A higher level of tocopherol was associated with a lower susceptibility to oxidation and a higher level of linoleic acid with an increased susceptibility. Robinson \& Coey (195I) and Lea (I953) have shown that the body fat from pigs given unsaturated fat is very susceptible to oxidation but can be protected by tocopherol. My results indicate that, even in the absence of large amounts of unsaturated fat in the diet, body fats are still susceptible to oxidation if there is not enough tocopherol. Although the diet contained less than $0 \cdot 1 \%$ linoleic acid, tocopherol was still necessary to protect against oxidation the small quantity of linoleic acid $\left(<_{\mathrm{I}} \%\right)$ and the larger amount of oleic acid $(>50 \%)$ stored in the back fat.

That one of the main functions of tocopherol in the pig is to prevent oxidation of the body lipids is in agreement with the present-day view that the major, if not the only, role of tocopherol in animal nutrition is that of a biological anti-oxidant (Bieri \& Briggs, I959; Machlin \& Gordon, 1960).

\section{Erythrocyte-haemolysis test}

The results of the dialuric-acid haemolysis test, carried out on blood samples obtained at various stages of Expt $I$, showed that neither the erythrocytes from the animals given tocopherol nor those from their controls were susceptible to haemolysis by dialuric acid. It appears therefore that either the small amount of tocopherol in the basal diet was sufficient to protect the erythrocytes from haemolysis or that the erythrocytes of tocopherol-deficient pigs are resistant to such haemolysis, as are those of the chick (Christensen, Dam, Gortner \& Søndergaard, I955-6).

Spontaneous haemolysis in $0.9 \%$ saline always occurred earlier in the erythrocytes from animals given $2 \%$ olive oil (pigs nos. $5,6,7$ and 8 ) than in those from animals on a low-fat diet (pigs nos. I, 2, 3 and 4). Only on one occasion was the susceptibility to haemolysis affected by tocopherol supplementation, otherwise there was no difference between pigs nos. 5 and 6 and pigs nos. 7 and 8 in this respect. It would appear therefore that dietary fat plays a more important part in the susceptibility of pig erythrocytes to haemolysis than does dietary tocopherol. 


\section{Unsaturated fatty acids of plasma, liver and heart}

Hove \& Seibold (1955) reported that supplementing diets containing $6 \%$ lard and $2 \%$ cod-liver oil with tocopherol increased the content of polyethenoid fatty acids in liver fat, but Garton et al. (1958) failed to confirm this finding using pigs given diets low in fat.

To find out whether this reported action of tocopherol in increasing the content of unsaturated fatty acids was peculiar to liver or whether it also occurred in other tissues, the fatty acids of plasma and heart as well as those of liver were analysed. It will be seen from Table 4 that there was no difference between the group given tocopherol and the control group in the content of any polyethenoid fatty acid, or in the iodine value and level of total plasma fatty acids.

The polyethenoid fatty-acid content of livers and hearts from the two groups of animals also showed no difference (Table 6). These results do not agree with those of Hove \& Seibold (I955), but it should be pointed out that the two experiments are not strictly comparable because of difference in the contents of fat in the diets. Tocopherol may affect the polyunsaturated fatty-acid content of various organs if there is sufficient unsaturated fat in the diet.

These experiments shed further light on the requirement of the pig for essential fatty acids. Previous work (Leat, I959) has shown that the growth of pigs up to $200 \mathrm{lb}$ live weight was the same whether the diet contained $0.03 \%$ or $0.22 \%$ linoleic acid although there were indications of skin disorders in the animals receiving $0.03 \%$ linoleic acid but not in those receiving $0.22 \%$ linoleic acid. The finding in the experiment reported here that the plasma content of trienoic acid at slaughter was $70 \%$ greater than that found half-way through the experiment indicates that the level of linoleic acid in the diet $(0.07 \%)$ was still insufficient to satisfy entirely the essential fatty-acid requirement of the pig.

\section{Unsaturated fatty acids of back fat}

Bratzler et al. (1950) reported that the feeding of tocopherol to pigs raised on a lowfat, low-tocopherol diet increased the oleic-acid content of back fat. This finding was not confirmed by Garton et al. (1958) or by Duncan et al. (1960). The results of Expt 2 indicate that although dietary tocopherol had been absorbed and stored there was no demonstrable effect either on the oleic-acid content or on the level of the more unsaturated fatty acids found in back fat (Table 5). In Expt $\mathbf{I}$ one of the pigs given tocopherol showed a rise in iodine value of the back fat which could be entirely accounted for by the greater content of linoleic acid in the back fat.

\section{SUMMARY}

I. The role of tocopherol in the nutrition of the pig reared from a weaning weight of Io $\mathrm{lb}$ live weight to a slaughter weight of $200 \mathrm{lb}$ live weight on a low-fat, lowtocopherol diet has been investigated.

2. In the first experiment, eight animals were used. Two animals received the basal 
diet only, two were given a supplement of $\alpha$-tocopheryl succinate $(5 \mathrm{mg} / \mathrm{roo} \mathrm{g}$ diet), two of olive oil $(2 \%)$ and the remaining two animals were given both olive oil and $\alpha$-tocopheryl succinate. There was no difference in growth rate between the groups and no abnormality in any organs or carcasses at slaughter. Plasma-tocopherol levels were two to seven times higher in the animals given tocopherol than in the controls. There was evidence of a deficiency of essential fatty acids in the animals not receiving supplements of olive oil.

3. In the second experiment two groups consisting of five animals each were reared on a slightly modified version of the diet used in the first experiment. One group only received supplements of $\alpha$-tocopheryl succinate ( $10 \mathrm{mg} / \mathrm{roO} \mathrm{g}$ diet). Again, there was no difference in growth rate and no abnormality in any organs or carcasses at slaughter. Plasma-tocopherol levels were seven to thirteen times higher in the animals given tocopherol than in the controls. There was no difference between the two groups in the content of unsaturated fatty acids of back fat, plasma, liver or heart. The peroxide levels in the back fat and liver lipids of the control animals were respectively twenty to fifty times and four to twenty times greater than found in the animals given tocopherol. Again, there were indications of an insufficiency of essential fatty acids in the basal diet.

4. It is concluded that the major function of tocopherol in the pig is to protect body lipids from oxidation.

My thanks are due to Mr R. D. Willis and Mr V. H. Thurlbourn for looking after the experimental animals and to $\mathrm{Mr} \mathrm{C}$. N. Saunders of the Veterinary Investigation Centre, Cambridge, for examining the animals at slaughter.

\section{REFERENCES}

Adamstone, F. B., Krider, J. L. \& James, M. F. (1949). Ann. N.Y. Acad. Sci. 52, 260.

Barnes, R. H., Lundberg, W. O., Hanson, H. T. \& Burr, G. O. (1943). F. biol. Chem. 149, 313.

Bieri, J. G. \& Briggs, G. M. (1959). Fed. Proc. 18, 5 I 7 .

Bratzler, J. W., Loosli, J. K., Krukovsky, V. N. \& Maynard, L. A. (1950). 7. Nutr. 42, 59.

Carpenter, L. E. \& Lundberg, W. O. (1949). Ann. N.Y. Acad. Sci. 52, 269.

Chipault, J. R., Lundberg, W. O. \& Burr, G. O. (1945). Arch. Biochem. 8, 32 r.

Christensen, F., Dam, H., Gortner, R. A. Jr. \& Søndergaard, E. (1955-6). Acta physiol. scand. $35,215$.

Duncan, W. R. H., Garton, G. A., McDonald, I. \& Smith, W. (r96o). Brit. F. Nutr. 14, 37 r.

Edwin, E. E., Diplock, A. T., Bunyan, J. \& Green, J. (1960). Biochem. F. 75, 450.

Eggitt, P. W. R. \& Ward, L. D. (1953). F. Sci. Fd Agric. 4, 569.

Garton, G. A., Duncan, W. R. H., Madsen, K. A., Shanks, P. L. \& Beattie, I. S. (1958). Brit. F. Nutr. r2, 97.

Gloor, U. \& Wiss, O. (1959). Arch. Biochem. Biophys. 83, 2 I6.

Herb, S. F. \& Riemenschneider, R. W. (1953). Analyt. Chem. 25, 953.

Hilditch, T. P. (1949). The Industrial Chemistry of the Fats and Waxes, $3 \mathrm{rd} \mathrm{ed,} \mathrm{p.} \mathrm{47.} \mathrm{London:} \mathrm{Baillière,}$

Tindall and Cox.

Hove, E. L. \& Seibold, H. R. (1955). F. Nutr. 56, 173.

Kimble, M. S. (1938-9). F. Lab. clin. Med. 24, 1055.

Lea, C. H. (1946). F. Soc. chem. Ind., Lond., 65, 286.

Lea, C. H. (1953). Chem. \& Ind. (Rev.), p. 13०3.

Leat, W. M. F. (ı959). Proc. Nutr. Soc. r8, xxxi.

Machlin, L. J. \& Gordon, R. S. (1960). Nutr. Rev. 18, 95.

Mervyn, L. \& Morton, R. A. (1959). Biochem. F. 72, 106.

Morton, R. A. \& Phillips, W. E. J. (1959). Biochem. F. 73, 427.

Pikaar, N. A. \& Nijhof, J. (1958). Biochem. F. 70, 52.

Reiser, R. (195 I). F. Nutr. 44, 159. 
Rieckehoff, I. G., Holman, R. T. \& Burr, G. O. (1949). Arch. Biochem. 20, 33 I.

Robinson, K. L. \& Coey, W. E. (195I). Nature, Lond., 168, 997.

Rose, C. S. \& György, P. (1952). Amer. F. Physiol. r68, 4 I4.

Slater, E. C. (1958). Int. Congr. Biochem. Iv. Vienna, II, 335.

Watts, B. M., Cunha, T. J. \& Major, R. (1946). Oil and Soap, 23, 254.

Wiese, H. F., Hansen, A. E. \& Baugham, M. A. (1957). F. Nutr. 63, 523.

Witz, W. M. \& Beeson, W. M. (I951). F. Anim. Sci. 1o, г 12.

Woodman, H. E. \& Evans, R. E. (195I). F. agric. Sci. 4X, 102. 